\title{
GROWTH AND NUTRIENT DIGESTIBILITY OF JELAWAT (Leptobarbus hoeveni) FRY FED WITH VARIOUS DIETARY PROTEIN LEVELS
}

\author{
Mas Tri Djoko Sunarno
}

\begin{abstract}
ABSTACT
A growth and nutrient digestibility study was executed for jelawat fry in the laboratory. The fry (40 day-old) were reared in 9 aquariums of $37.5 \mathrm{~L}$ water volume at 30 per tank and fed an isocaloric diet $(4.2 \mathrm{kcal})$ containing 3 dietary protein levels $(33,40,47 \%)$ at $10 \%$ of body weight a day for 49 days. Biomass was weighed fortnightly. Chromic oxide $(1 \%)$ was added to each experimental diet for the digestibility study, which was conducted in 3 conical tanks of $100 \mathrm{~L}$ water volume each. The results indicated that the effects of dietary protein levels on fish growth and feed conversion efficiency were significantly different. A positive quadratic equation was found for the response of fish growth as well as feed conversion efficiency to various dietary protein levels. Maximum growth and high feed conversion efficiency were observed at about $40 \%$ protein level. This feed was well digested by the fry with rates of $76.6,98.3,97.7,54.0$, and $98.2 \%$ for dry matter, protein, fat, carbohydrate and energy, respectively.
\end{abstract}

KEYWORDS: jelawat, fry, protein, digestibility, Leptobarbus hoeveni, maroon shark

\section{INTRODUCTION}

The wild-riverine species, jelawat, maroon shark (Leptobarbus hoeveni) is a popular table fish and an ornamental fish in Indonesia, especially Sumatra and Kalimantan and in other countries such as Malaysia and Thailand. Its culture has been practised in Indonesia since 1940 and tended to develop rapidly. This species has successfully spawned in a hatchery since 1980 (Ondara and Sunarno, 1987). It was observed that one pair of brooders could yield 15,000 fingerlings, however, this was still lower than its fecundity of 73,000 eggs $/ \mathrm{kg}$ fish. Low seed production is mainly caused by lack of availability of natural food in the hatchery. Cho et al. (1985) suggested rearing fish in a tank with artificial feed containing a balance of nutrients and energy.

Protein is the main factor of a feed formulation to achieve high growth and feed efficiency of fish. Protein is required to build body-protein and as an energy source. Low protein input causes slow growth. However, excess protein input results in inefficiency and indirectly increases ammonia- $\mathrm{N}$ in water that at certain level could affect negatively on fish growth (NRC, 1983). Therefore, an optimum level of dietary protein should be determined to enhance maximum potential growth rate of fish in a control tank. It was identified that dietary protein level for maximum growth rate of fish varies, depending on species, size, culture condition, physiological condition, feed formulation, and dietary energy level. In general, Lovell in Yamada (1983) stated that omnivorous species required a dietary protein range of about $30-36 \%$. Pathmasothy and Omar (1981a) found dietary protein level for enhancing maximum growth of jelawat fingerlings at $38 \%$ in conditions of dietary energy of 2.5 $\mathrm{cal} / \mathrm{kg}$ feed and using practical feed ingredients. Lower dietary protein (30\%--34\%) was observed for jelawat of the same size if the experimental diet was semipurified with dietary energy level of $3.6 \mathrm{cal}$ (Pathmasothy and Omar, 1981b). However, information on protein requirement for jelawat fry was not available. Therefore, this experiment was conducted to evaluate dietary protein for maximum growth of 40 day-old jelawat fry. In addition, the digestibility of this feed was also evaluated

\section{MATERIAL AND METHODS}

Conducted in the laboratory, this study was divided into two parts: evaluating the growth response to dietary protein levels of jelawat fry and the apparent digestibility of different dietary protein levels. A Completely Randomized Design was used.

Three isocaloric feeds were used in this study. Dietary energy was adjusted to an equal level for all experimental feeds at $4.07 \mathrm{Mcal} / \mathrm{kg}$ feed. Dietary protein varied, namely $33,40,47 \%$ (Table 1 ).

Casein was used as the main source of protein and its content varied in the feed composition. Soybean meal, coconut cake meal, corn meal, rice bran meal, tapioca, vitamin premix, and mineral premix were added in the same percentage for all experimental feeds. Both vitamin and mineral premixes were made based on recommendations of NRC (1977) for common carp fry. In addition, fish oil and corn oil were added in feed formulations at different levels to reach equivalent energy content of feed, but its ratio was 
Table 1. Feed formulation (\%) for jelawat (L. hoeveni) fry used in the experiment

\begin{tabular}{|c|c|c|c|}
\hline \multirow{2}{*}{ Ingredient } & \multicolumn{3}{|c|}{ Dietary protein (\%) } \\
\hline & 33 & 40 & 47 \\
\hline Casein & 21.05 & 29.76 & 38.46 \\
\hline Soybean meal & 27.00 & 27.00 & 27.00 \\
\hline Coconut cake & 7.00 & 7.00 & 7.00 \\
\hline Corn meal & 3.00 & 3.00 & 3.00 \\
\hline Rice bran & 1.00 & 1.00 & 1.00 \\
\hline Tapioca & 2.00 & 2.00 & 2.00 \\
\hline Fish oil & 8.35 & 6.11 & 3.86 \\
\hline Corn oil & 8.35 & 6.11 & 3.86 \\
\hline Vitamin premix* & 0.60 & 0.60 & 0.60 \\
\hline Mineral premix* & 3.65 & 3.65 & 3.65 \\
\hline Avicell & 18.00 & 13.77 & 9.57 \\
\hline Total & 100 & 100 & 100 \\
\hline \multicolumn{4}{|c|}{ Energy and chemical composition of feed ( $\%$ in dry basis) } \\
\hline Moisture & 8.60 & 8.80 & 8.20 \\
\hline Crude protein & 32.91 & 40.60 & 47.82 \\
\hline Crude fat & 19.16 & 13.97 & 9.11 \\
\hline Ash & 6.14 & 6.86 & 5.08 \\
\hline Crude fibre & 7.60 & 6.36 & 5.33 \\
\hline NFE & 34.19 & 32.21 & 32.66 \\
\hline Gross energy & 4.05 & 4.12 & 4.10 \\
\hline
\end{tabular}

Note: *: formulated following NRC (1977)

fixed at 1:1. Avicell (non-nutritive feed ingredient) (NRC, 1977) was added to all experimental feeds in different levels to get $100 \%$ feed composition.

Proximate analysis for all feed ingredients as well as pelletised feed was done in the chemical laboratory of the Research Institute for Freshwater Fisheries (RIFF). To each experimental feed, $1 \% \mathrm{Cr}_{2} \mathrm{O}_{3}$ was added for evaluation of feed digestibility (Jobling, 1983; Cho et al., 1985).

Jelawat fry used in this study were obtained from one pair of brooders spawned using hormone treatment in the Jambi Research Laboratory of RIFF Station Palembang. Boiled chicken yolk egg was given to the two-day old fry for a week; thereafter, natural food collected from a lake by plankton net was given to the fry for the next 2 weeks. About 10,000 fry were transferred to the tanks and acclimatized to experimental conditions and fed on the test diet for 15 days.

Acclimatized fish fry of about $0.065 \mathrm{~g}$ were randomly distributed to 9 prepared aquariums at a rate of 30 fry per aquarium of $50 \times 30 \times 30 \mathrm{~cm}$. Each container was filled with $37.5 \mathrm{~L}$ ground water. Aerators were used in the aquariums to maintain high dissolved oxygen concentration. In addition, siphoning faeces as well as excess feed if available was conducted daily. Every two days and week, water in each aquarium was changed at 75 and $100 \%$ of total water volume, respectively.

The fry were fed on the experimental feed at $10 \%$ of body weight per day, divided into 5 seeding times from early morning to afternoon, namely at 06.00 , $09.00,12.00,15.00$, and 18.00. Rations were adjusted every week after fish weighing. Fish carcasses were collected at the start and end of the experiment as subject of proximate analysis.

The digestibility study was done in three conical tanks filled with $100 \mathrm{~L}$ water. Two sizes of fry were tested for their feed digestion, namely $0.080 \mathrm{~g}$ and $0.350 \mathrm{~g}$, according to fish weight gained in the dietary protein study. About $20 \mathrm{~g}$ fish weight was stocked in each conical tank and then fasted for 24 hours to allow gastointestine tract emptying. Test diets containing different dietary protein levels were given to the fish ad libitum three times per day, namely at 06.00 12.00, and 18.00. Thirty to sixty minutes after feeding, excess feed in each tank was pumped out with 
flowing water from the bottom part of the tank. Faeces trapped in a bottle prepared in the bottom part of the conical tank were collected every two hours. The faeces were separated from the water by pipette, dried in an oven for 24 hours and then stored in dried state. This was done after the amount of faeces was enough for proximate and $\mathrm{Cr}_{2} \mathrm{O}_{3}$ analysis. The procedure of $\mathrm{Cr}_{2} \mathrm{O}_{3}$ analysis followed recommendations of Djobo (1983)

Data were analyzed for growth rate (Ricker, 1979); feed efficiency (NRC, 1977); protein retention, fat retention and energy retention (Viola and Rappaport, 1979); and nutrient and energy digestibility (NRC, 1983). Response to treatment of tested parameters was assessed with the F test (Snedecor and Cochran. 1980). Maximum value was determined by calculating first derivation of a quadratic equation (Dabrowski, 1977).

Relative growth rate was calculated as follows

$$
W_{t}=W_{0} e^{k t}
$$

where: $W_{t}$ is fish weight at time $t(g), W_{0}$ is initial fish weight $(\mathrm{g}), \mathrm{k}$ is relative growth rate, $\mathrm{t}$ is time (day), and $e$ is a constant equal to 2.7183

Feed efficiency (E) was calculated as follows:

$$
E(\%)=\left\{\left(W_{t}+D\right)-W_{0}\right\} \times 100 /(F)
$$

Where: $W_{\text {t }}$ is fish weight at time $t(g), W_{0}$ is initial fish weight $(\mathrm{g}), \mathrm{D}$ is dead fish weight during experiment (g), and F is amount of feed given to the fish (g)

Retention of protein, fat and energy were calculated as follows
Protein/fat retention $(\%)=$

$\{($ Weight of protein or fat in fish body, $g) \times$ $100\} /$ (Weight of protein or fat in feed consumed, g)

Energy retention (\%) =

$\{$ (Energy content in fish body, kcal) $\times 100\} /$ (Energy in feed consumed, $\mathrm{g}$ )

Digestible nutrient/energy was calculated as follows:

Digestibility of nutrient/energy =

$100-100 \times\left\{\left(\% \mathrm{Cr}_{2} \mathrm{O}_{3}\right.\right.$ in feed $\times \%$ nutrient or energy in faeces $) /\left(\% \mathrm{Cr}_{2} \mathrm{O}_{3}\right.$ in faeces $x \%$ nutrient or energy in feed)\}

\section{RESULTS}

\section{Growth and Feed Efficiency}

Mean weight of fry recorded weekly during the experimental period is presented in Fig. 1. All fry response to dietary protein follows an exponential curve pattern, although they differ from one another. Fry fed on low dietary protein grew less. Increase in dietary protein up to about $40 \%$ tended to increase fish weight. However, increasing the dietary protein level up to $47 \%$ did not increase fish weight.

Effects of dietary protein levels on relative growth rate, feed efficiency, nutrient, and energy retention for jelawat fry are presented in Table 2. Different dietary protein levels had significant effects on relative growth rate of jelawat fry. Low dietary protein intake resulted in slow growth. The growth improved when fry were fed on higher protein levels. However, dietary protein

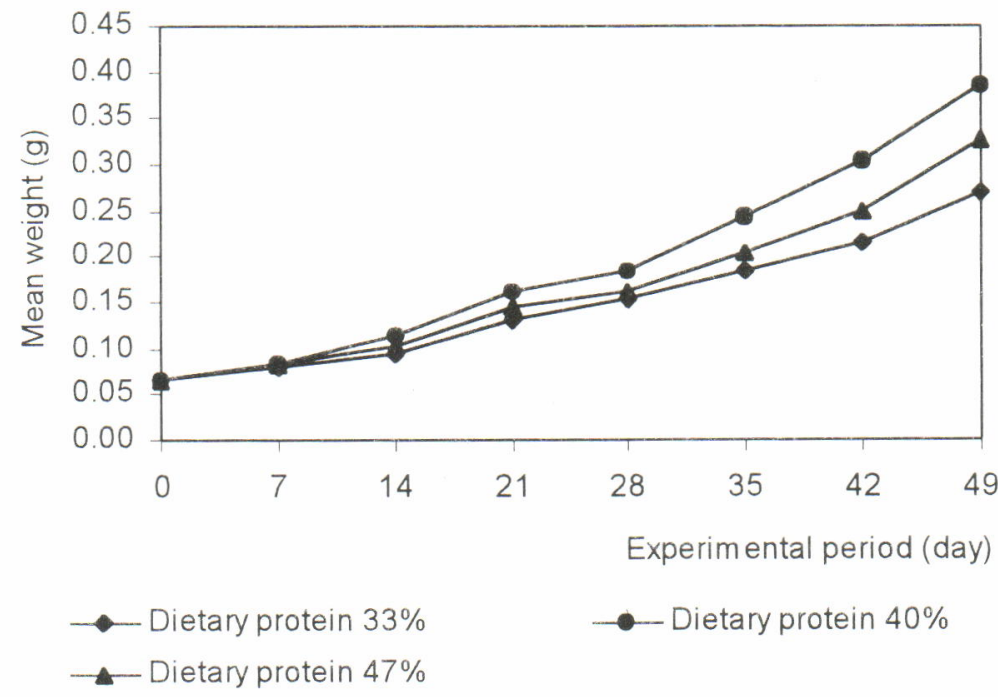

Fig. 1. Mean weight of jelawat (L. hoeveni) fry fed different dietary protein levels 
Table 2. Relative growth rate, feed efficiency (after transformating to arcsine $\sqrt{ } \%$ ), protein/energy retention of jelawat $(L$. hoeveni) fry fed on different dietary protein levels (value $\pm S D$ )

\begin{tabular}{lrrr}
\hline \multicolumn{1}{c}{ Indices } & Protein 33\% & Protein 40\% & Protein $\mathbf{4 7 \%}$ \\
\hline Relative growth rate, $\mathrm{k}$ & $0.029 \pm 0.001$ & $0.036 \pm .001$ & $0.032 \pm .001$ \\
Feed efficiency (\%) & $33.3 \pm 2.72$ & $41.37 \pm 1.28$ & $39.16 \pm 4.32$ \\
Protein retention (\%) & $13.87 \pm 1.09$ & $15.43 \pm 0.36$ & $11.32 \pm 1.24$ \\
Fat retention (\%) & $11.25 \pm 0.74$ & $15.72 \pm 0.53$ & $23.35 \pm 2.43$ \\
Energy retention (\%) & $10.88 \pm 0.83$ & $12.66 \pm 1.38$ & $12.44 \pm 1.34$ \\
\hline
\end{tabular}

above $40 \%$ could not enhance fry growth. Responses of relative growth rate $\left(Y_{\text {) }}\right)$ of fry to dietary protein levels $(X)$ can be expressed in positive quadratic equation as follows:

$$
Y_{0}=-0.155+0.00936 X+0.000114 X^{2}
$$

From this equation, the maximum dietary protein level for jelawat fry could be determined. Calculations showed that dietary protein at about $40 \%$ resulted in maximum potential growth rate of jelawat fry.

Evaluation of feed efficiency of dietary protein levels also supported the phenomena in fish growth. The effect of different dietary protein levels on feed efficiency of jelawat fry was significantly different. Response of feed efficiency $\left(Y_{1}\right)$ to dietary protein can be expressed in an equation as follows:

$Y_{1}=-69.5908+5.2316 X+0.0623 X^{2}$, (after transformating to arcsine $\sqrt{ } \%$ )

The highest feed efficiency of jelawat fry was at about $40 \%$ dietary protein.

\section{Retention of Protein, Fat, and Energy}

Data on body protein and fat of jelawat fry before and after feeding on the experimental diet are presented in Table 3. Before and after feeding on the experimental diet, body protein was comparable, however, body fat tends to increase.
Results of calculation of retention of protein, fat, and energy are presented in Table 2. Anova analysis showed that retention of protein and fat was significantly affected by dietary protein. Retention of energy did not differ between treatments.

Retention of protein $\left(\mathrm{Y}_{2}\right)$ increased from dietary protein $33 \%$ to $40 \%$ and there after decreased at $47 \%$, following the equation:

$$
Y_{2}=-48.0589+3.7170 X+0.0484 X^{2}
$$

The maximum point of retention of protein was at about $40 \%$ dietary protein.

Retention of fat $\left(\mathrm{Y}_{3}\right)$ linearly increased with increasing dietary protein, following the equation:

$$
Y_{3}=-2.5798+0.6629 X
$$

\section{Digestibility of Nutrients and Energy}

Results of feed digestion by jelawat fry are given in Table 4. Anova showed that effect of dietary protein on feed digestibility of fish was significantly different. Protein and energy digestion were not affected by dietary protein levels.

Response of digestibility of fry to different dietary levels followed positive quadratic equation for dry matter $\left(\mathrm{Y}_{4}\right)$, fat $\left(\mathrm{Y}_{5}\right)$, and carbohydrate $\left(\mathrm{Y}_{6}\right)$, respectively. The equations are as follows:

Table 3. Composition of protein and fat in body of jelawat ( $L$. hoeveni) fry before and after feeding on experimental diet

\begin{tabular}{lccc}
\hline \multicolumn{1}{l}{ Dietary protein (\%) } & Body protein (\%) & Body fat (\%) \\
\hline Before feeding & & 63.85 & 19.06 \\
After feeding & & & \\
& 33 & 63.34 & 27.64 \\
40 & 64.67 & 22.34 \\
& 47 & 64.52 & 24.30 \\
\hline
\end{tabular}


Table 4. Digestibility of nutrients and dry matter of jelawat $(L$. hoeveni) fry fed on different dietary protein levels

\begin{tabular}{lrrr}
\hline \multirow{2}{*}{ Indices } & \multicolumn{3}{c}{ Dietary protein (\%) } \\
\cline { 2 - 4 } & $\mathbf{3 3}$ & $\mathbf{4 0}$ & $\mathbf{4 7}$ \\
\hline Dry matter digestion (\%) & 64.12 & 76.62 & 71.40 \\
Protein digestion (\%) & 95.72 & 98.32 & 97.84 \\
Fat digestion (\%) & 94.7 & 97.74 & 90.82 \\
Carbohydrate digestion (\%) & 39.81 & 53.99 & 47.14 \\
Energy digestion (\%) & 95.14 & 98.17 & 96.94
\end{tabular}

$Y_{4}=-115.057+8.545 X-0.102 X^{2}$

$Y_{5}=-129.634+10.859 X-0.140 X^{2}$

$Y_{6}=-162.632+10.193 X-0.124 X^{2}$

The equations show that jelawat fry could digest dry matter, fat and carbohydrate at rates as high as $75.17,97.51$, and $53.12 \%$, respectively.

\section{Parameters of Water Quality in the Aquarium}

Table 5 shows that the measurement of some parameters of water quality in each tank receiving different dietary protein levels. Water quality is normal for supporting growth of jelawat fry.

\section{DISCUSSION}

Low mortality during the experimental period showed that water environment in each aquarium was good for the fry of jelawat. Exponential fish growth indicated that the experimental fish were in the fast growth phase. Slow initial growth occurred because of the short acclimation period.

Figure 1 shows that dietary protein of about $40 \%$ is suitable for supporting maximum potential growth of jelawat fry. This is also supported by data of relative growth rate, feed efficiency, retention of protein and energy, and digestibility of nutrient and energy.
Growth rate of fish relates highly to fish weight. The gain of fish weight depends on protein intake. In conditions of adequate energy intake, the use of protein in the metabolic process is affected by available non-protein energy, particularly fat. Slow growth of fry fed on $33 \%$ dietary protein may be caused by less available protein instead of high dietary fat. Duppre et al. (1979) reported that the growth rate of channel catfish decreased when fish were fed a dietary fat level of $15 \%$ to $20 \%$. However, less dietary fat in high dietary protein $(47 \%)$ may result in utilization of feed protein as an energy source for its metabolism; therefore, less growth is also observed for fish fed on $47 \%$ dietary protein. The ratio of protein-energy in feed for maximum growth rate of jelawat fry in this experiment is $100 \mathrm{mg}$ protein/kcal GE.

The optimal dietary protein of $40 \%$ for jelawat fry found in this study is similar to the level recommended for fingerlings $(2 \mathrm{~g})$ of jelawat by Pathmasothy \& Omar (1981a); channel catfish (Garling and Wilson, 1976); common carp (Ogino and Saito, 1970); grass carp (Dabrowski, 1977); mujair (Jauncy, 1982). The values for growth rate and feed efficiency of those species are also comparable (growth rate $=3 \%$ and feed efficiency $40 \%$ ). However, this finding is still lower than that for other fish culture practices. Growth rate and feed efficiency higher than $5 \% /$ day and $60 \%$, respectively, are suitable and profitable in culture practice. Frequent fish handling in experimental conditions and

Table 5. Some parameters of water quality in tanks of fish fed different dietary protein levels

\begin{tabular}{lccc}
\hline \multirow{2}{*}{ Indices } & \multicolumn{3}{c}{ Dietary protein (\%) } \\
\cline { 2 - 4 } & $\mathbf{3 3}$ & $\mathbf{4 0}$ & $\mathbf{4 7}$ \\
\hline Temperature $\left({ }^{\circ} \mathrm{C}\right)$ & 26.0 & 26.0 & 26.0 \\
Ammonia- $\mathrm{N}(\mathrm{mg} / \mathrm{L})$ & $0.018-0.023$ & $0.023-0.030$ & $0.042-0.051$ \\
$\mathrm{pH}$ & $8.04-8.06$ & $8.01-8.03$ & $7.91-8.03$ \\
Alkalinity $\left(\mathrm{mg} \mathrm{CaCO}_{3} / \mathrm{L}\right)$ & $183.2-184.0$ & $182.4-188.4$ & $185.2-187.2$ \\
\hline
\end{tabular}


lack of natural feed may affect growth performance of fish.

Table 3 shows that body protein of fish before and after feeding tended to be unchanged, however, body fat tended to increase. Thus, isocaloric feed using fat as the main energy source may increase body fat. According to Pfeffer (1982), relatively stable body protein may indicate that capacity of protein synthesis in the fish body has achieved maximum rate, essential amino acids used for synthesising non-essential amino acids, or less available metabolism energy for synthesising body protein. This is also found in common carp (Ogino and Saito, 1970) and grass carp (Dabrowski, 1977) fed protein of $38 \%$ to $60 \%$.

Based on the protein retention, the dietary protein level for maximum protein retention was about $38.42 \%$. High protein diet increases fat body because excess protein intake will be changed into energy and kept in the fish body as fat. Therefore, fat retention in this study increased linearly with increasing protein intake. According to Ogino and Saito (1970), the value of maximum protein retention is more realistic to determining the protein requirement of fish.

Feed quality could be shown by its digestibility. In general, jelawat fry was able to digest the ration indicated by high value of dry matter digestibility. This experiment shows that dietary protein is totally digested by jelawat fry and not affected by its levels. Austreng \& Refstie (1979) stated that differences of protein digestion were observed when dietary protein level is below $30 \%$. Tilapia fed on $10 \%$ to $30 \%$ dietary protein was able to digest protein at a linear rate. The rate declined, thereafter, when protein level increased (De Silva and Perera, 1984).

Fat used as the main source of feed energy was well digested by jelawat fry at a rate of $91 \%$ to $98 \%$. The highest value of fat digestion in jelawat fry was observed with fish fed on $40 \%$ dietary protein. Declining fat digestion at $47 \%$ dietary protein may relate to proteolytic enzyme action. NRC (1977) stated that after feeding a high protein diet, proteolitic enzyme activities of fish would be triggered to increase, thus decreasing fat digestion. The ability of jelawat fry to digest protein and fat well accords to the food habit of the fish in nature which is to feed preferably on zooplankton containing high protein as well as fat.

Data on carbohydrate digestion show that increase in dietary protein up to $40 \%$ could increase carbohydrate digestion, which then declined when dietary protein increased up to $47 \%$. Maximum dietary protein, well digested by jelawat fry, was also observed at about $40 \%$

In conclusion, jelawat fry after 40 days age raised in controlled conditions could be fed with artificial feed formulated using natural feed ingredients to contain a protein level of $36 \%$ to $40 \%$. The ratio of protein energy in feed is about $100 \mathrm{mg}$ protein $/ \mathrm{kcal}$.

\section{REFERENCES}

Austreng, E. and J. Refstie. 1979. Effect of varying dietary protein level in different families of rainbow trout. Aquaculture, 18: 145--146.

Cho, C.Y.; C.B. Cowey; and T. Watanabe. 1985. Finfish Nutrition in Asia. Methodological Approaches to Research and Development. IDRC., Ottawa.

Dabrowski. K. 1977. Protein requirements of grasscarp fry (Ctenopharyngodon idella Val.). Aquacuiture, 12: $63-73$

De Silva, S.S. and M.K. Perera. 1984. Digestibility in Sarotherodon niloticus fry: Effect of dietary protein level and salinity with further observations on variability in daily digestibility. Aquaculture, 38: 293--306

Djobo, J. 1983. Utilization de proteines bacteriennes dans l'alimentation de la digestibilite. D.E.A. D'Oceanographie Biolgique. Uni. Pierre, Marie Curie, Paris, $35 \mathrm{pp}$

Dupree, H.K.; E.J. Gauglitz; A.S. Hall; and C.R. Houle. 1979. Effect of dietary lipids on the growth and acceptability (flavour) of channel catfish (/ctalurus punctatus), In: J.E. Halver and K. Tiews (Eds.) Finfish nutrition and fishfeed technology, Vol. II. Proc. World Symp. on Finfish Nutrition and Fishfeed Technology, Hamburg, 20--23 Jun 1978, Berlin. p:437-44

Garling, D.L. and R.P. Wilson. 1976. The optimum dietary calorie to protein ratio for channel catfish fingerlings, Ichtalurus punctatus. J. Nutrition, 106: 1369$-1375$

Jauncey, K. 1982. The effect of varying dietary protein level on the growth, food conversion, protein utilization and body composition of juvenil tilapias (Sarotherodon mossambicus). Aquaculture, 27:43--54

Jobling, M. 1983. A short review and critique of methodology used in fish growth and nutrition studies. $J$. Fish Biol., 23: 685--703.

NRC. 1977. Nutrient Requirements of Warmwater Fishes. Nat. Acad. Sci. Washington, D.C. 71 pp.

NRC. 1983. Nutrient Requirements of Warmwater Fishes and Shellfishes. Rev. Ed. Nat. Acad. Sci. Washington, D.C. $86 \mathrm{pp}$

Ogino, C. and K. Saito. 1970. Protein nutrition in fish, l: The utilization of dietary protein by young carp. Bull. Jpn. Soc. Fish. Sci., 36: 250--254.

Ondara and M.T.D. Sunarno. 1987. Pemijahan ikan jelawat (Leptobarbus hoeveni Blkr.) dengan sunikan hormon dalam sangkar terapung di Danau Teluk Jambi. Bull. Penel. Perik. Darat, 1: 21--28.

Pathmasothy, S. and R. Omar. 1981a. Preliminary Study on the Effect of Four Different Peletized Formulation Diets on the Growth of Leptobarbus hoeveni. MARDI Sta. Batuberendam, Malacca, $7 \mathrm{pp}$.

Pathmasothy, S. and R. Omar. 1981b. Growth Performance of Leptobarbus hoeveni Fingerling Fed /so- 
caloric Diets with Variable Protein Levels. MARDI Sta. Batuberendam, Malacca, $13 \mathrm{pp}$.

Pfeffer, E. 1982. Utilization of dietary protein by salmonid fish. Comp. Biochem. Physiol., 73B: 51--57.

Ricker, W.E. 1979. Growth rates and models. In: W.S. Hoar, D.J. Randall and J.R. Brett (Eds.). Fish Physio/ogy Vol. VIII. Acad. Press New York. p: 678--744

Snedecor, G.W. and W.G. Cochran. 1980. Statistical Methods ( $7^{\text {th }}$ ed). The lowa State Univ. Press, lowa. 507 pp
Viola, S. and U. Rappaport. 1979. The extra calorie effect of oil in the nutrition of carp. Bamidgeh, 31: 51--69.

Yamada, R. 1983. Pond production systems: Feed and feeding practice in warmwater fish pond. In: J.E. Lanan, R.O. Smitherman and G. Tchobanoglous (Eds). Principles and Practices of Pond Aquaculture: A State and The Art Reviews. Oregon States Univ. Oregon. p: 117--144. 
